\title{
Effects of motor exercises upon life quality of adolescents subjected to hematopoietic stem cell transplantation
}

\author{
Alla A. Potapchuk ${ }^{1}$, Alisa G. Volkova ${ }^{1}$, Fedor V. Terentiev ${ }^{2}$, Irina G. Terentieva ${ }^{2}$, Ludmila S. Zubarovskaya ${ }^{1}$, \\ Boris V. Afanasyev ${ }^{1}$ \\ ${ }^{1}$ Raisa Gorbacheva Memorial Research Institute of Pediatric Oncology, Hematology and Transplantation, Pavlov University, \\ St. Petersburg, Russia \\ ${ }^{2}$ National State P. F. Lesgaft University of Physical Culture, Sports and Health, St. Petersburg, Russia \\ Dr. Fedor V. Terentiev, National State P.F. Lesgaft University \\ E-mail: fedterentev@mail.ru
}

of Physical Culture, Sports and Health, St. Petersburg,

Russia

Citation: Potapchuk AA, Volkova AG, Terentiev FV et al. Effects of motor exercises upon life quality of adolescents subjected to hematopoietic stem cell transplantation. Cell Ther Transplant 2019; 8(4): 62-67.

\section{Summary}

The present article is evaluating the effects of physical rehabilitation upon the quality of life (QoL) indexes in adolescents (12 to 17 y.o.) with oncological diseases following hematopoietic stem cell transplantation (HSCT). The proprietary technique of physical rehabilitation includes 3 stages with nine complexes of physical exercises, dependent on their age and regimen of motor activities. We have evaluated QoL, and anxiety/depressive conditions in adolescents at three stages of the study: HSCT, after it, and following rehabilitation. The data obtained confirm a positive effect of the physical rehabilitation upon QoL in the adolescents with cancer subjected to hematopoietic stem cell transplantation.

\section{Keywords}

Physical rehabilitation, oncology, children, hematopoietic stem cell transplantation, depression, anxiety, emotional state.

\section{Introduction}

At the present time, a sufficient attention is paid to changing quality of life (QoL) during rehabilitation programs in young patients with tuberculosis and other chronic conditions $[1,2]$. Life quality aspects in children and adults after hematopoietic stem cell transplantation is also in focus of current studies [3-7]. In this view, the effects of physical rehabilitation seems to exert positive effects upon quality of life in early posttransplant period.

QoL is an common category meaning an integrity of physical, psychological, emotional and social functioning. Determination of the QoL indexes is included into evaluation scoring of rehabilitation programs [8].

Over last years, a distinct trend for increased cancer morbidity worldwide, including children and adolescents [9]. 300,000 cases of cancer are registered yearly in children from 0 to 18 years old. In 2016, 24207 children were registered at oncological dispensariesn in Russia, thus requiring appropriate rehabilitation programs following cancer therapy.

The effects of physical rehabilitation upon QoL of adolescents with cancer following HSCT is poorly studied so far. Our aim was to propose an original system of post-transplant physical rehabilitation and tools of appropriate QoL control.

\section{Patients and methods}

The study included twenty patients at the age of 12 to 17 years old. The study was performed at the base of R. Gorbacheva Research Institute of Children Onclogy, Hematology and Transplantology over a period of April 2017 to November 2018. Ten patients were in experimental group 1 , and 10 , in experimental group 2 . The $1^{\text {st }}$ group received a standard program of physical exercises, whereas $2^{\text {nd }}$ group was subject to additional program of physical rehabilitation. 
To resolve our clinical tasks, we have developed and tested a program of physical rehabilitation for adolescents with cancer diseases after HSCT procedure. This method is aimed for effective recovery of functional state, prevention of complications, QoL increase, psychophysical development of the patients subjected to HSCT at different rehabilitation stages.

This purpose was achieved by resolution of some educational and health-sparing health-promoting tasks at the 3 time stages of the program:

1. Pre-transplant;

2. During the early posttransplant period (over 30-40 days);

3. At the later posttransplant period (over D+100).

Educational tasks are obligatory for each phase of the physical rehabilitation. They include: developing positive attitude for physical exercises; development of physical abilities during the studies; education of aesthetic and moral personal properties (honesty, discipline, responsibility etc.). Posing the health-promoting tasks depends on the disease severity, secondary disturbances of different organs and systems as well as existing comorbidities.

At each stage of the program, certain specific tasks were perform, as follows:

1. Before transplantation:

- to prepare the organism for the ongoing therapeutic procedure;

- to promote sufficient levels of adaptational abilities in the patient;

- to educate positive attitude for the motor activity exercises.

2. Early posttransplant period:

- to promote recovery of the functional systems of the organism;

- to develop and restore motor abilities;

- to perform prevention of complications and concomitant diseases;

- to optimize psycho-emotional state of the patient.

3. Late posttransplant period:

- further promotion of physical abilities;

- development of functional systems in the patient;

- to foster volitional powers in the subjects' personality;

- to increase the level of emotional state.

Design of the program was based on the following pedagogical principles: availability and individualization, gradually increasing duration and intensity of exercises, activity and consciousness of the subjects involved; continuity of pedagogical activity in the course of rehabilitation, differential approach to application of physical exercises. Organizational and methodical features of physical rehabilitation for adolescents with cancer diseases: keeping the treatment and general regimen at the clinical facility; taking into account the types and forms of physical exercises; engraftment degree; education and preparation for the next rehabilitation step, high-quality self-consistent performance of the physical exercises; prophylaxis of the complications caused by low motor activities.

The developed program of physical rehabilitation consists of the following components:

1) Active games, aimed for correction and development of sensory, perceptive, psychomotor, emotional and volitional properties, voluntary attention and memory, communicative skills, e.g., Just a Minute, Nose-Year, Mirror etc.

2) Active games aimed for development of fine motor skills, respiratory functions, restoration of motor skills, after longterm hypodynamy when staying in bed, games in order to improve physical characteristics of the patients, i.e., Balls in the basket, Rope-walker, Spinner.

3) Physical exercises should be health-promoting, with elements of extension and static tension, respiratory and corrective exercises with adaptive sport elements. Hockey on the floor, sitting volleyball.

The program includes 9 sets which were dependent on the rehabilitation stage and age of the patient. The exercise sets consisted of basic and variative parts. The basic part included obligatory exercises, whereas variative part consisted of games that could be chosen of a certain list, aiming for solution of distinct tasks for the given rehabilitation phase, as shown in Table 1.

Contents of the exercise sets were variable, depending on age and rehabilitation period. I.e., exercises for the children of 12-13 years are more simple and require less repeats that those for adolescents in the age of 14-15 or 16-17 years.

Short description of the physical exercises applied includes the movement regimens, initial positions, amplitude and pace of the exercises, ratio of fitness gym and special exercises (respiratory, correcting exercises with adaptive sport elements). Short characteristics of their contents are presented in Table 2.

Recent publications on dosage of loads for physical rehabilitation of children after HSCT are controversial and methodologically different $[10,11,12]$.

The authors propose individual dosage, depending on physical potential of the patients and terms posttransplant. E.g., Yildiz Kabak et al. suggest usage of the Borg scale despite

Table 1. Variable exercise sets included into the physical rehabilitation program

\begin{tabular}{|l|l|l|l|}
\hline \multirow{2}{*}{ Rehabilitation period } & \multicolumn{3}{|c|}{ Age, years } \\
\cline { 2 - 5 } & $12-13$ & $14-15$ & $16-17$ \\
\hline Before transplantation & №1 & №4 & №8 \\
\hline Early posttransplant period & №2 & №5 & №9 \\
\hline Late posttransplant period & №3 & №6 & \\
\hline
\end{tabular}


its subjectivity based on pulse rates of adult persons [13]. To perform dosage for physical loads, some special devices are applied, e.g., Actiwatch-Score-type pulsometers, or a portable monitor for the pulse rate measurements. However, they are intended for routine screening, and it is difficult to perform effective scheduling of long-term programs $[11,14]$.

Some reports present dosage variants for physical loadings with its gradual increment, variability and adaptation, depending on the patients' condition. Meanwhile, we did not find any data on dosage of physical loads for adolescents during the pre-transplant period. Therefore, we planned loadings based on the developed original regimens, general principles and requirements for age-adapted physical exercises $[15,16]$.

The physical load was optimal and corresponded to functional abilities for adolescents. A number of factors was considered when planning the dosage of physical load, aiming for its increase or reduction: initial laying or sitting caused reduced load; staying posture was associated with increased load; switching of small muscular groups (foot, hand) were connected with decreased loadings. Increased amplitude of the movements and repeat numbers did also increase physical loads. The exercises were performed slowly, at moderate rates, or rapidly; rhythmic exercises alleviated the loads. A demand for exact performance caused initial increase of physical load, while decreasing later, upon automation of movements. Complex exercises with motor coordination did enhance the load, thus having been excluded from initial first-stage classes, and were introduced gradually; the exercises for relaxation and static respiratory exercises caused a decreased load (the load became lesser, the more this exercise was repeated. The ratios between health-promoting and special exercises were $1: 1 ; 1: 2 ; 1: 3 ; 1: 4 ; 1: 5$, and positive emotions during the classes in the form of games helped to better tolerate physical loads. Different grade of the patient's efforts when performing the exercises proved to promote variation of loadings. In order to manage physical loadings, we used a principle of the load spreading with alternative involvement of different muscle groups; usage of different apparatus influenced the intensity of physical load.

When performing this program of physical exercises, their general load depended on their intensity, duration, density and volume. The intensity corresponded to certain threshold level for given step of the program. Duration of the load was adequate to performance time for each distinct task. The total volume of loads and their density was distributed uniformly, with their intensity determined by individual features of the patient and stage of the program. The motion regimen, dosage, density and total volume of the loads depended on the patient's age and stage of the given rehabilitation program.

When arranging content of the game complexes and physical exercise sets we followed the principle "from a simple to more complex", i.e., from minor muscular groups to major ones, depending on the patient's age. The games were classified into four groups with increasing loads: 1) On-site passive games; 2) Less active games; 3 ) Active games; 4) Elements of

Table 2. Brief description of exercise sets for different posttransplant patients

\begin{tabular}{|c|c|c|c|c|c|c|}
\hline $\begin{array}{l}\text { № Complex } \\
\text { №. }\end{array}$ & Kinetic regimen & $\begin{array}{l}\text { Dosage, } \\
\text { min. }\end{array}$ & Initial position & $\begin{array}{l}\text { Movement } \\
\text { amplitude }\end{array}$ & $\begin{array}{l}\text { Rhythm of } \\
\text { exercise }\end{array}$ & $\begin{array}{l}\text { General fitness/ } \\
\text { special exercises }\end{array}$ \\
\hline №า & $\begin{array}{l}\text { Free mode } \\
\text { Ward regimen }\end{array}$ & $10-15$ & $\begin{array}{l}\text { Supine } \\
\text { Sitting } \\
\text { Staying }\end{array}$ & Medium & $\begin{array}{l}\text { Slow } \\
\text { Medium } \\
\text { Fast }\end{array}$ & 1:3 \\
\hline №2 & $\begin{array}{l}\text { Bed regimen } \\
\text { Semi-bed rest } \\
\text { Ward regimen }\end{array}$ & $10-15$ & $\begin{array}{l}\text { Supine } \\
\text { Sitting }\end{array}$ & Low & Slow & 1:5 \\
\hline №3 & $\begin{array}{l}\text { Free mode } \\
\text { Training }\end{array}$ & $20-30$ & $\begin{array}{l}\text { Sitting } \\
\text { Staying }\end{array}$ & $\begin{array}{l}\text { Medium } \\
\text { to large }\end{array}$ & $\begin{array}{l}\text { Medium } \\
\text { Fast }\end{array}$ & $1: 2$ \\
\hline №4 & $\begin{array}{l}\text { Free mode } \\
\text { Ward regimen }\end{array}$ & $10-15$ & $\begin{array}{l}\text { Sitting } \\
\text { Staying }\end{array}$ & $\begin{array}{l}\text { Medium } \\
\text { to large }\end{array}$ & $\begin{array}{l}\text { Slow } \\
\text { Medium } \\
\text { Fast }\end{array}$ & 1:3 \\
\hline №5 & $\begin{array}{l}\text { Bed regimen } \\
\text { Semi-bed rest } \\
\text { Ward regimen }\end{array}$ & $10-15$ & $\begin{array}{l}\text { Sitting } \\
\text { Staying }\end{array}$ & Low & Slow & $1: 4$ \\
\hline №6 & $\begin{array}{l}\text { Free mode } \\
\text { Training }\end{array}$ & $20-30$ & $\begin{array}{l}\text { Supine } \\
\text { Sitting } \\
\text { Staying }\end{array}$ & $\begin{array}{l}\text { Medium } \\
\text { to large }\end{array}$ & $\begin{array}{l}\text { Medium } \\
\text { Fast }\end{array}$ & 1:1 \\
\hline №7 & $\begin{array}{l}\text { Free mode } \\
\text { Ward regimen }\end{array}$ & $10-15$ & $\begin{array}{l}\text { Sitting } \\
\text { Staying }\end{array}$ & $\begin{array}{l}\text { Medium } \\
\text { to large }\end{array}$ & $\begin{array}{l}\text { Medium } \\
\text { Fast }\end{array}$ & $1: 2$ \\
\hline №8 & $\begin{array}{l}\text { Bed regimen } \\
\text { Semi-bed rest } \\
\text { Ward regimen }\end{array}$ & $10-15$ & $\begin{array}{l}\text { Supine } \\
\text { Sitting }\end{array}$ & Low to medium & $\begin{array}{l}\text { Slow } \\
\text { Medium }\end{array}$ & $1: 3$ \\
\hline №9 & $\begin{array}{l}\text { Free mode } \\
\text { Training regimen }\end{array}$ & $20-30$ & $\begin{array}{l}\text { Sitting } \\
\text { Staying }\end{array}$ & Large & $\begin{array}{l}\text { Medium } \\
\text { Fast }\end{array}$ & 1:1 \\
\hline
\end{tabular}


sports games. The games allowed usage of selective effects, exact intensity dosage for differently directed game exercises.

To evaluate efficiency of the the program, we used the QoL assessment using the special questionnaire (PedsQL Stem Cell Transplant Module Version 1.0) [14, 17].

Statistical evaluation of the results was performed by the STATISTICA 7.0 (StatSoft,CШA). At initial stage, we evaluated the type of distribution by means of Shapiro-Wilkes criterion. Since most indexes did not show a standard distribution, the non-parametric methods were used. Significance of appropriate differences between the median values was evaluated by the Mann-Whitney test, with $\mathrm{p}<0.05$ taken as a value of significance.

\section{Results}

The analysis of QoL in the children following HSCT has shown statistically significant differences between the groups 1 and $2(\mathrm{p}<0.05)$ by all the scales of Questionnaire. The indexes were registered at all 3 stages of the program. The PedsQL Stem Cell Transplant Module data are shown in Table 3 and Fig. 1.
Evaluation of QoL indexes in adolescents subjected to HSCT allowed us to assess a statistically significant improvement of QoL by all the questionnaire scales. The indexes regularly decreased at the $2^{\text {nd }}$ rehabilitation stage after HSCT, and increased at the $3^{\text {rd }}$ rehabilitation stage, showing improved QoL for most indexes in experimental group 2, as compared to the $1^{\text {st }}$ group.

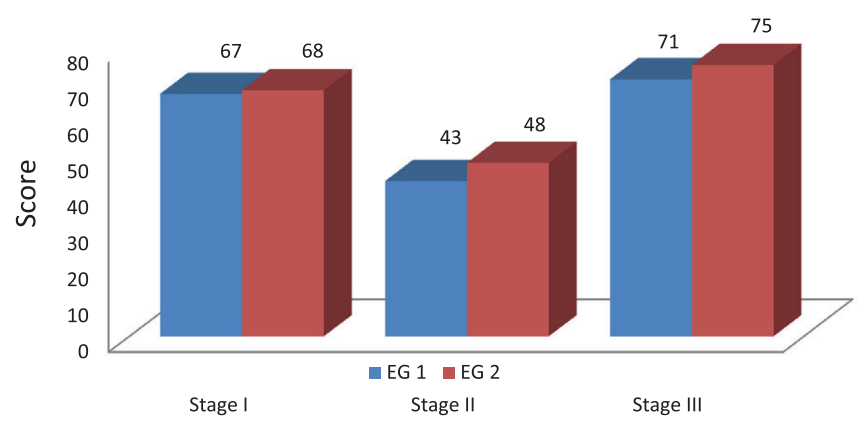

Figure 1. Quality of life indexes at the 3 stages of study in the 2 experimental groups

Table 3. Quality of life scores in posttransplant adolescents at different stages of rehabilitation program

\begin{tabular}{|c|c|c|c|c|c|c|}
\hline \multirow[t]{2}{*}{ Questionnaire scales } & \multicolumn{2}{|c|}{ Stage I } & \multicolumn{2}{|c|}{ Stage II } & \multicolumn{2}{|c|}{ Stage III } \\
\hline & Group 1 & Group 2 & Group 1 & Group 2 & Group 1 & Group 2 \\
\hline Physical functioning & $\begin{array}{l}59 \\
(51 ; 70)\end{array}$ & $\begin{array}{l}62 \\
(55 ; 75)\end{array}$ & $\begin{array}{l}40 \\
(26 ; 51)\end{array}$ & $\begin{array}{l}45^{\star} \\
(30 ; 55)\end{array}$ & $\begin{array}{l}58 \\
(50 ; 65)\end{array}$ & $\begin{array}{l}72^{\star} \\
(60 ; 81)\end{array}$ \\
\hline Emotional functioning & $\begin{array}{l}68 \\
(57 ; 78)\end{array}$ & $\begin{array}{l}66 \\
(56 ; 75)\end{array}$ & $\begin{array}{l}50 \\
(40 ; 60) \\
\end{array}$ & $\begin{array}{l}56^{*} \\
(47 ; 66)\end{array}$ & $\begin{array}{l}59 \\
(51 ; 66)\end{array}$ & $\begin{array}{l}72^{\star} \\
(60 ; 79)\end{array}$ \\
\hline Social functioning & $\begin{array}{l}63 \\
(51 ; 73) \\
\end{array}$ & $\begin{array}{l}63 \\
(50 ; 69) \\
\end{array}$ & $\begin{array}{l}43 \\
(35 ; 53)\end{array}$ & $\begin{array}{l}45^{*} \\
(39 ; 57) \\
\end{array}$ & $\begin{array}{l}62 \\
(50 ; 74) \\
\end{array}$ & $\begin{array}{l}65^{\star} \\
(60 ; 69) \\
\end{array}$ \\
\hline Total score, points & $\begin{array}{l}63 \\
(53 ; 73) \\
\end{array}$ & $\begin{array}{l}63 \\
(53 ; 73) \\
\end{array}$ & $\begin{array}{l}44 \\
(33 ; 54) \\
\end{array}$ & $\begin{array}{l}48^{\star} \\
(38 ; 59) \\
\end{array}$ & $\begin{array}{l}59 \\
(50 ; 68) \\
\end{array}$ & $\begin{array}{l}68^{\star} \\
(60 ; 76) \\
\end{array}$ \\
\hline Pain & $\begin{array}{l}70 \\
(50 ; 89)\end{array}$ & $\begin{array}{l}68 \\
(53 ; 83)\end{array}$ & $\begin{array}{l}37 \\
(20 ; 54)\end{array}$ & $\begin{array}{l}40^{\star} \\
(27 ; 54)\end{array}$ & $\begin{array}{l}71 \\
(50 ; 92)\end{array}$ & $\begin{array}{l}70^{\star} \\
(50 ; 91)\end{array}$ \\
\hline Tiredness and sleep & $\begin{array}{l}60 \\
(53 ; 68)\end{array}$ & $\begin{array}{l}63 \\
(58 ; 68)\end{array}$ & $\begin{array}{l}35 \\
(20 ; 50)\end{array}$ & $\begin{array}{l}38^{\star} \\
(21 ; 55)\end{array}$ & $\begin{array}{l}57 \\
(50 ; 65)\end{array}$ & $\begin{array}{l}65^{*} \\
(61 ; 70)\end{array}$ \\
\hline Nausea & $\begin{array}{l}80 \\
(69 ; 92) \\
\end{array}$ & $\begin{array}{l}82 \\
(73 ; 92) \\
\end{array}$ & $\begin{array}{l}50 \\
(30 ; 70) \\
\end{array}$ & $\begin{array}{l}57^{\star} \\
(40 ; 74) \\
\end{array}$ & $\begin{array}{l}82 \\
(75 ; 90) \\
\end{array}$ & $\begin{array}{l}90^{\star} \\
(85 ; 90) \\
\end{array}$ \\
\hline Restlessness & $\begin{array}{l}60 \\
(55 ; 67)\end{array}$ & $\begin{array}{l}65 \\
(50 ; 65) \\
\end{array}$ & $\begin{array}{l}41 \\
(35 ; 48)\end{array}$ & $\begin{array}{l}47^{\star} \\
(37 ; 55)\end{array}$ & $\begin{array}{l}70 \\
(60 ; 79) \\
\end{array}$ & $\begin{array}{l}80^{\star} \\
(70 ; 91) \\
\end{array}$ \\
\hline Nutrition & $\begin{array}{l}70 \\
(53 ; 70)\end{array}$ & $\begin{array}{l}69 \\
(50 ; 87)\end{array}$ & $\begin{array}{l}30 \\
(25 ; 30)\end{array}$ & $\begin{array}{l}33^{*} \\
(20 ; 47)\end{array}$ & $\begin{array}{l}73 \\
(66 ; 80)\end{array}$ & $\begin{array}{l}75^{\star} \\
(69 ; 81)\end{array}$ \\
\hline Mental ability & $\begin{array}{l}80 \\
(63 ; 97) \\
\end{array}$ & $\begin{array}{l}83 \\
(76 ; 90) \\
\end{array}$ & $\begin{array}{l}60 \\
(50 ; 72) \\
\end{array}$ & $\begin{array}{l}66^{*} \\
(53 ; 78)\end{array}$ & $\begin{array}{l}79 \\
(65 ; 93)\end{array}$ & $\begin{array}{l}80^{\star} \\
(66 ; 95) \\
\end{array}$ \\
\hline Communication & $\begin{array}{l}50 \\
(30 ; 73)\end{array}$ & $\begin{array}{l}47 \\
(33 ; 61)\end{array}$ & $\begin{array}{l}50 \\
(27 ; 72)\end{array}$ & $\begin{array}{l}55^{\star} \\
(30 ; 77)\end{array}$ & $\begin{array}{l}65 \\
(50 ; 80)\end{array}$ & $\begin{array}{l}70^{*} \\
(60 ; 80)\end{array}$ \\
\hline Total score, points & $\begin{array}{l}67 \\
(53 ; 79)\end{array}$ & $\begin{array}{l}68 \\
(56 ; 78)\end{array}$ & $\begin{array}{l}43 \\
(27 ; 56)\end{array}$ & $\begin{array}{l}48^{*} \\
(32 ; 62)\end{array}$ & $\begin{array}{l}71 \\
(59 ; 82)\end{array}$ & $\begin{array}{l}75^{\star} \\
(65 ; 85)\end{array}$ \\
\hline
\end{tabular}

Note: The data are expressed as points of the QoL questionnaire scores ${ }^{*}, \mathrm{p}<0.05$ means a statistically significant difference between group 1 and group 2. 
When summarizing the data obtained, one may see that all the life quality indexes of were substantially decreased after HSCT in both experimental groups. However, during the rehabilitation measures, implementing the proposed program, a normalization and increase of parameters was revealed in experimental groups, especially by the indexes of physical functioning $(+14 \%)$, emotional functioning $(+11 \%)$, and communication abilities $(+33 \%)$, thus confirming efficiency of the proposed physical rehabilitation program with respect to quality of life in the patients.

The data obtained confirm a positive effect of motor activities upon quality of life in adolescents subjected to hematopoietic stem cell transplantation reported elsewhere $[13,16]$.

\section{Conclusion}

1. At the present time, a number of children with cancer is registered worldwide, thus often requiring severe chemotherapy and hematopoietic stem cell transplantation (HSCT).

2. We have proposed a program of physical rehabilitation in children with cancer diseases, including nine variative sets of exercises. The technique consists of game exercises, fitness, respiratory and corrective exercises as well elements of adaptive sport.

3. The quality of life was evaluated by means of a PedsQL Stem Cell Transplant Questionnaire. Following HSCT, all the QoL indexes were decreased in both groups, i.e., with standard program of physical exercises (Group 1), and group 2 subjected to additional physical programs.

4. The course of rehabilitation in the patients from group 2 who used the proposed additional program has resulted into physical normalization and more pronounced increase in QoL, when compared to the children receiving standard physical exercises.

\section{References}

1. Solokhina LV, Dyachenko EI, Yarinchuk EI. Studies on quality of life in tuberculosis-affected children. Far-Eastern Medical Journal. 2010; No.1: 134-137 (In Russian).

2. Romanova LA, Kulishova TV, Nesina IA. Time dynamics of life quality in the children of school age with innate cervical spinal trauma following combined sanatory treatment, including manual therapy. Journal of Siberian Medical Sciences. 2014; No.4:180-187 (In Russian).

3. Takken T, van der Torre P, Zwerink M, Hulzebos EH, Bierings M, Helders PJ, van der Net J. Development, feasibility and efficacy of a community-based exercise training program in pediatric cancer survivors. Psychooncology. 2009; 18(4):440-448.

4. Parsons SK, Tighiouart H, Terrin N. Assessment of health-related quality of life in pediatric hematopoietic stem cell transplant recipients: progress, challenges and future directions. Expert Rev Pharmacoecon Outcomes Res. 2013; 13: $217-225$.
5. Lawitschka A, Güclü ED, Varni JW, Putz M, Wolff D, Pavletic S, Greinix H, Peters C, Felder-Puig R. Health-related quality of life in pediatric patients after allogeneic SCT: development of the PedsQL Stem Cell Transplant module and results of a pilot study. Bone Marrow Transplant. 2014; 49: 1093-1097.

6. Hastings B, Patil C, Gallo AM. The experience and health-related quality of life after haploidentical stem cell transplantation for adults with sickle cell disease. West J Nurs Res. 2019;18:193945919870828. doi: $10.1177 / 0193945919870828$.

7. Zając-Spychała O, Pieczonka A, Barańska M, Wachowiak J. Long-term recipient health-related quality of life and donor-recipient relationship following sibling pediatric hematopoietic stem cell transplantation. Biol Blood Marrow Transplant. 2019 pii: S1083-8791(19)30665-2/ doi: 10.1016/j. bbmt.2019.10.009.

8. Ivannikova AS, Pochivalov AV. Quality of life in children with respiratory diseases associated with non-differentiated dysplasia of connective tissue. The BelGU Research Notes (Medical and Pharmaceutic Series). 2012; No.16(135):47-49 (In Russian).

9. Kaprina AD, Starinsky VV, Petrova GV. State of oncological care for the population of Russia in 2016. P.Gerzen Research Institute of Oncology: Moscow, 2017, pp. 18-19 (In Russian).

10. van Brussel M, Takken T, van der Net J, Engelbert RH, Bierings M, Schoenmakers MA, Helders PJ. Physical function and fitness in long-term survivors of childhood leukaemia. Pediatr Rehabil. 2006; 9(3):267-274.

11. San Juan AF, Chamorro-Viña C, Moral S, Fernández del Valle M, Madero L, Ramírez M, Pérez M, Lucia A. Benefits of intrahospital exercise training after pediatric bone marrow transplantation. Int J Sports Med. 2008;29(5): 439-446.

12. Norris JM, Moules NJ, Pelletier G, Culos-Reed SN. Families of young pediatric cancer survivors: a cross-sectional survey examining physical activity behavior and health-related quality of life. J Pediatr Oncol Nurs. 2010; 27(4):196208.

13. Yildiz Kabak V, Cetinkaya DU, Kuskonmaz B, Cetin N, Duger T. Effects of multimodal exercise on clinical status and patient-reported outcomes in children undergoing hematopoietic stem cell transplantation. Pediatr Hematol Oncol. (2019) 36(7):410-421.

14. Danaher EH, Ferrans C, Verlen E, Ravandi F, van Besien K, Gelms J, Dieterle N. Fatigue and physical activity in patients undergoing hematopoietic stem cell transplant. Oncol Nurs Forum. 2006; 33:614-624.

15. Rosenhagen A, Bernhörster M, Vogt L, Weiss B, Senn A, Arndt S, Siegler K, Jung M, Bader P, Banzer W. Implementation of structured physical activity in the pediatric stem cell transplantation. Klin Pädiatr. 2011;223(3):147-151. 
16. Yildiz Kabak V, Duger T, Cetinkaya D. Investigation of the effects of an exercise program on physical functions and activities of daily life in pediatric hematopoietic stem cell transplantation. Pediatr Blood Cancer. 2016;63 (9):16431648.
17. Brice L, Weiss R, Wei Y, Satwani P, Bhatia M, George D, Garvin J, Morris E, Harrison L, Cairo MS, Sands SA. Health-related quality of life (HRQoL): the impact of medical and demographic variables upon pediatric recipients of hematopoietic stem cell transplantation. Pediatr Blood Cancer. 2011;57(7):1179-1185.

\title{
Влияние двигательной активности на качество жизни подростков, перенесших трансплантацию гемопоэти- ческих стволовых клеток
}

\author{
Алла А. Потапчук ${ }^{1}$, Алиса Г. Волкова ${ }^{1}$, Федор В. Терентьев ${ }^{2}$, Ирина Г. Терентьева ${ }^{2}$, Людмила С. Зубаровская ${ }^{1}$, \\ Борис В. Афанасьев ${ }^{1}$ \\ ${ }^{1}$ НИИ детской онкологии, гематологии и трансплантологии им. Р. М. Горбачевой, Первый Санкт-Петербургский \\ государственный медицинский университет им. акад. И. П. Павлова, Санкт-Петербург, Россия \\ ${ }^{2}$ Национальный государственный университет физической культуры, спорта и здоровья им. П. Ф. Лесгафта, \\ Санкт-Петербург, Россия
}

\section{Резюме}

Данная статья посвящена анализу влияния физической реабилитации на показатели качества жизни подростков 12-17 лет с онкопатологией после трансплантации гемопоэтических стволовых клеток (ТГСК). Авторская методика физической реабилитации включает три этапа, включающие девять комплексов физических упражнений в зависимости от возраста и режима двигательной активности. Проводилась оценка качества жизни, оценивался уровень тревожно-депрессивных состояний подростков на трех этапах исследования: до проведения трансплантации, после трансплантации, после реабилитации. Полученные данные свидетельствуют о положительном влиянии физической реабилитации на качество жизни подростков с онкопатологией, перенесших трансплантацию гемопоэтических стволовых клеток.

\section{Ключевые слова}

Физическая реабилитация, онкология, дети, трансплантация гемопоэтических стволовых клеток, депрессия, тревога, эмоциональное состояние. 